\title{
O pojęciu normatywności w ocenie zaburzenia umysłowego ${ }^{1}$
}

\author{
Sebastian Muders \\ Department of Philosophy, Center for Ethics, \\ University of Zurich, Zurich, Switzerland \\ sebastian.muders@ethik.uzh.ch \\ Przełożył Przemysław Nowakowski
}

\begin{abstract}
Abstrakt
W artykule Marco Striera "Normative preconditions for the assessment of mental disorder" pojęcie normatywności zajmuje centralne miejsce (Stier, 2013). Stier stwierdza, że zaburzenia umysłowe posiadają wbudowany nieredukowalny element normatywny, możliwy do wyrażenia przez różne powiązane z nim „normatywne ramy odniesienia”. Zgodnie z jego dwiema głównymi tezami, uważa on, że ramy te kształtują to, co uznajemy za zachowanie dewiacyjne, a co za niedewiacyjne. Uznaje on to za świadectwo tego, że zaburzenia umysłowe musimy określać na poziomie umysłowym, a więc nigdy nie będziemy w stanie przedstawić ich w czysto fizycznym ujęciu. Niestety Strier nigdzie jasno nie przedstawił, co uznaje za treść pojęcia normatywności, ale w różnych miejscach dawał wskazówki, jak je rozumie. W dalszej części zbadam jego trzy sugestie dotyczące istotnych powiązań, które pojęcie normatywności wnosi do innych pojęć: nienaturalności, nieobiektywności i względności. Będę uzasadniał, że wątpliwe jest, czy to rozumienie prowadzi do konkluzji, do której zmierza Stier - że określenie zaburzenia umysłowego nie może powieść się na poziomie fizycznym, a jedynie na umysłowym, z powodu wpływu na to przedsięwzięcie rozważań nad normatywnością.
\end{abstract}

\footnotetext{
${ }^{1}$ Przekład artykułu pt. „On the concept of the normative in the assessment of mental disorder” opublikowanego w Frontiers in Psychology, February 2014, Volume 5, Article 129, source: https://www.ncbi.nlm.nih.gov/pmc/articles/PMC3925841/

DOI: 10.3389/fpsyg.2014.00129 Przekład opublikowano na mocy licencji Creative Commons Attribution License (CC BY).

${ }^{2}$ Stier, M. (2013). Normative preconditions for the assessment of mental disorder. Frontiers in Psychology, 4:611. DOI: 10.3389/fpsyg.2013.00611
} 
Słowa kluczowe: pojęcie zaburzeń umysłowych; nienaturalny; obiektywność; względność; normatywność

\section{Normatywność i nienaturalność}

W odniesieniu do relacji pomiędzy normatywnością i nienaturalnością Stier twierdzi, że normatywność nie może zostać uchwycona w kategoriach naturalistycznych. Łączy ten rzekomy fakt z własną dychotomią ontologiczną na to, co umysłowe i to, co naturalne. $\mathrm{Z}$ tego wynika według niego, że normatywność musi należeć do sfery umysłowej, bo „wydaje się, że jest coś szczególnego w zachowaniu, coś, co wykracza poza czysto fizyczne wyjaśnienia, z powodu tego, że, powiedzmy, różnica pomiędzy działaniem uprzejmym i nieuprzejmym jest trudna do uchwycenia przy pomocy nienormatywnych, fizycznych kategorii" (s.1).

Obie myśli wydają się problematyczne. W odniesieniu do pierwszej, istnieje wielu filozofów zmierzających do objaśnienia wszystkich rodzajów faktów normatywnych związanych z ludzkim zachowaniem, w kategoriach naturalistycznych, zatem redukując normatywne do naturalnego. To, co Derek Parfit nazywa „analitycznym naturalizmem” (porównaj: Parfit 2011, p. 295), zmierza właśnie do przedefiniowania pojęć normatywnych w kategoriach pojęć naturalnych. Parfit wspomina Nicholasa Sturgeona i Franka Jacksona jako wybitnych zwolenników naturalizmu tego typu (Parfit 2011, p. 365).

To, czy ci autorzy mają racje, czy nie, z pewnością może być dyskusjne, ale ich wysiłki sugerują przynajmniej, że branie zjawiska na wiarę bez choćby wspomnienia podejść konkurencyjnych trudno uznać za właściwą strategię. W istocie Strieri sam daje ważny przykład prima facie nieredukowalnej dziedziny ontologicznej innej niż to, co fizyczne: sam umysł jest często uważany za poważne wyzwanie dla zatwardziałych naturalistów. Niemniej jednak przyznaje (przynajmniej dla celów swojego artykułu), że „każdy poszczególny aspekt naszego zachowania i życia umysłowego może być wyjaśniony w czysto fizycznych kategoriach" (p. 2) - z czego, oczywiście, jawnie wyklucza zaburzenia umysłowe. Jednak jeżeli zdecydowana większość zjawisk umysłowych może być wyjaśniona w kategoriach naturalnych, dlaczego to samo nie może być możliwe w przypadku zjawisk normatywnych?

Po drugie, wydaje się, że nie ma intuicyjnego sposobu na połączenie faktu, że coś jest nienaturalne, $\mathrm{z}$ faktem, że jest umysłowe. Bardzo wiele z rzeczy mogących służyć za paradygmatyczne przykłady bytów nienaturalnych nie jest postrzegane jako z konieczności umysłowe w interesujący nas tu sposób: Bóg, liczba siedem, godność ludzka - są one oczywiście ideami normatywnymi. Na przykład Bóg jest niemal z definicji nienaturalny, lecz jego pojęcie z pewnością nie wymaga od nas wyobrażania go sobie jako czegoś umysłowego. 
W istocie to, że pewien normatywny byt nie może być uchwycony w naturalnych kategoriach, nie oznacza, że w ogóle musi być redukowalny do jakiejkolwiek innej dziedziny. Przeciwnie, normatywne aspekty zaburzeń umysłowych, które okażą się niepodatne na analizy w kategoriach naturalnych, mogą być, zwyczajnie, nieredukowalnymi aspektami normatywnymi. Dla dużej części dziedziny normatywnej to powszechne rozwiązanie. Przykładowo, Russ ShaferLandau twierdzi, że powinniśmy „wprowadzić do naszej ontologii kategorię wartości sui generis”, która może wyjaśnić normatywność moralności (porównaj: Shafer-Landau 2003: 55). Jeśli uda się przedstawić podobne podejście dla normatywnych aspektów zaburzeń umysłowych, nie będzie potrzeby zakładania, że zaburzenia umysłowe powinny być określane na poziomie umysłowym.

\section{Normatywność i nieobiektywność}

Rozważmy teraz nieobiektywność. Analizując różne rodzaje normatywnych ram odniesienia, Stier często używa założenia o normatywności pewnego faktu jako racji uznania go za nieobiektywny.

Ograniczę się do dwóch przykładów. Badając ocenianie racjonalności i to, jak opiera się ono na przypisywaniu zaburzeń umysłowych, stwierdza, że „jest to [...] kwestia wyboru normatywnego, a nie obiektywnego sądu, czy racjonalność jest, czy nie jest uważana za składnik zdrowia umysłowego" (s. 4). Często uznajemy irracjonalne zachowanie za wskaźnik choroby umysłowej, stąd przypisanie tego drugiego, jeśli dokonane podstawie tego pierwszego, również staje się sądem nieobiektywnym.

Jeden z argumentów Stiera wspierających jego rozstrzygnięcie opiera się na ogólnej obserwacji, że jedna i ta sama osoba może być przedmiotem różnego traktowania przez innych ludzi i przez władze, w zależności od tego, czy pewne irracjonalne zachowania są, czy nie są uważane za spowodowane zaburzeniami umysłowymi. Zatem zgodnie $\mathrm{z}$ „tezą o zmiennych standardach” [Switching-Standard-Thesis] Stiera, sądy o racjonalności nie są „obiektywną” normą mierzenia czyjegoś zdrowia umysłowego.

Jednak ten argument zawodzi. We wszystkich obserwacjach Stiera okazuje się, że nasze reakcje zmieniają się zależnie od domniemanego źródła irracjonalnego zachowania (które to może być przedmiotem argumentu z najlepszego wyjaśnienia): jeśli mamy powód, by myśleć, że irracjonalne zachowanie pewnej osoby wynika z jej psychologicznego pragnienia, którego ona nie rozpoznaje jako części swojej osobowości, to słusznie jesteśmy bardziej skłonni do interwencji. W związku z tym to nie jest tak, jakoby sądy normatywne o czyjejś racjonalności zmieniały swoją ważność z „prawdziwe” na „fałszywe” lub jakoby fakt, że ktoś zachowuje się irracjonalnie, był jakoś ontologicznie zależny od czynników subiektywnych; zmieniają się jedynie dostarczone nam powody 
praktyczne. I nie przedstawiono żadnych argumentów, że powody te są nieobiektywne, a jedynie że ich treść zależy od dalszych rozważań, których status nie jest jeszcze jasny.

Stier odnajduje analogiczny błąd, gdy względy moralne są wykorzystywane do oceny zdrowia psychicznego: „twierdzę [...] że wiele stanów [zaburzeń psychicznych] - lub stanów w wielu okolicznościach - przynajmniej obejmuje elementy normatywne (moralne) i dlatego nie mogą być wolnymi od wartości, nienormatywnymi (obiektywnymi) rodzajami medycznymi” (s. 5).

Założenie Stierego, że wiele rodzajów zaburzeń umysłowych posiada wbudowane oceny moralne i dlatego nie jest „obiektywnych” w znaczeniu „tam, niezależnie od naszej subiektywnej oceny”, zdaje się mylić ludzkie opinie na temat właściwej moralności z samą moralnością. Przykładowo, pisze on, że „,[w] bardzo religijnym społeczeństwie bycie ateistą może być uważane za zaburzenie osobowości” (s. 5). To prawda - lecz o ile nie akceptujemy płytkiego subiektywizmu w formie „myślenie, że coś jest dobre, czyni to dobrym”, o tyle opinie o moralności nie są z konieczności prawdziwe. W związku z tym zaburzenie umysłowe zdiagnozowane częściowo w oparciu o moralnie złe zachowanie, może być przypisane fałszywie, a nie jedynie arbitralnie (a jednak poprawnie).

\section{Normatywność i względność}

Na koniec, pragnę przyjrzeć się zakładanej przez Stiera relacji pomiędzy normatywnością i względnością. Używa on pojęcia względności w różnych miejscach i przywołuje je jako świadectwo tego, że oparta na wartościach natura zaburzeń umysłowych nie może być uważana za podatną na czysto naturalną analizę tej pierwszej. Reasumując, stwierdza, że „[p]sychiatria kieruje się normami społecznymi, moralnymi, kulturowymi i innymi. Jeśli to prawda i jeśli prawdziwe jest również to, że te rodzaje norm zależą od czasu i miejsca, to psychiatria nie może przyjmować, że wie, czym jest zaburzenie umysłowe „samo w sobie”, gdzie normalność się kończy, a zaburzenie umysłowe zaczyna” (p. 3).

Fragment, w którym uzasadnia on ten ostatni cytat, jest objaśnieniem wpływu względności kulturowej na to, co jest uznawane za zaburzenie umysłowe. Odróżnia wpływ bezpośredni od pośredniego. Pierwszy odnosi do „ukształtowania kulturowego” [,cultural setup”] społeczeństwa, które tworzy normy, za którymi muszą podążać należące do niego jednostki. W zależności od ich osobowości jednostki mogą uważać, że bardzo trudno poradzić sobie z oczekiwaniami wyrażonymi w tych normach, i z tego powodu uzyskiwać wyższe wyniki w pewnych kryteriach dla określonych zaburzeń psychologicznych.

To, że częstotliwość pojawiania się zaburzeń psychologicznych koreluje z charakterem kulturowym i osobowością, jest niezbyt zaskakujące i „względne” jedynie w najbardziej nieinteresującym znaczeniu tego terminu. Dobrze znany 
jest fakt, że temperatura wrzenia wody zależy wielu czynników, włącznie z ciśnieniem atmosferycznym. Jak na razie to nie powstrzymuje go przed byciem zarówno naturalnym, jak i obiektywnym. A ani charakter kulturowy, ani osobowość, nie są czymś, na co jednostka może dowolnie wpływać w stopniu istotnym dla większości zaburzeń psychicznych. Zgodnie z tym rozumowaniem warunek Striera, by problemy psychologiczne musiały być „takie same na całym świecie”, aby uzyskać naukowe wyjaśnienie (np. p. 7), jest stanowczo przesadzone.

Wraz z „bezpośrednim wpływem” Strier wskazuje na tezę, że właściwości kultury mogą nie tylko wyzwalać rozwój zaburzeń umysłowych u ludzi z pewnymi osobowościami, ale także „dążą do narzucenia granicy pomiędzy normalnością a dewiacją na podstawie oczekiwanych wartości i cnót jej członków” (p. 6). Ponownie przykład używany przez Strieriego ma sens jedynie, gdy założymy, że nie ma sposobu, by ocenić poprawność kryteriów proponowanych dla zaburzeń umysłowych w danej kulturze. To, że „[k]toś, kto jest «dynamiczny» w jednym $\mathrm{z}$ regionów kulturowych, może być uznany za napastliwego $\mathrm{w}$ innym” (p. 7) nie mówi nam nic o tym, czy rzeczywiście powinien być uważany za napastliwego.

Strier uważa, że nie istnieje „ostateczna odpowiedź” na to pytanie, uznając, że różne modele wyjaśniania $\mathrm{w}$ psychologii konstytuują różne „podstawowe normy eksplanacyjne” dla określania, czym jest zburzenie umysłowe. Zatem „nie ma po prostu wyższego poziomu obiektywności, z którego moglibyśmy ocenić wartość tego czy innego ujęcia eksplanacyjnego" (s. 7). Aby uzasadnić tę śmiałą tezę, argumentuje, że nawet pozornie „twarde” kryteria takie jak „efektywność wyjaśnień i powiązanych terapii” nie mogą dostarczyć nam rozwiązań, ponieważ to, który z rywalizujących modeli wyjaśniania „,jest najbardziej efektywny, jest nawet dzisiaj przedmiotem dyskusji” (s. 8). Jednak sam fakt, że dyskusja nadal trwa, nie upoważnia do myślenia, że nigdy nie zostanie zakonczona przez racjonalną wymianę, jak już 30 lat temu przyznali zwolennicy argumentu ze względności (Mackie 1977, 36 i następne).

Podsumowując, twierdzenie, że zaburzenia umysłowe posiadają pewien „aspekt normatywny” nie musi ani oznaczać, że są one objaśniane jedynie na poziomie umysłowym czy też nie mogą być określone obiektywnie, ani że istnieją czy są rozpoznawane jedyne w stosunku do norm kulturowych. Niedostarczenie ich pełnej „naturalnej” charakterystyki może być całkowicie kompatybilne z ujęciem, że są one, jak pisze Strier, „tam na zewnątrz” i raczej muszą zostać odkryte, a nie skonstruowane. A ponieważ nie każdy aspekt normatywny musi wymagać redukcji do tego, co naturalne, umysłowe czy jakiekolwiek inne, nic nie musi być zgubione w przekładzie. 


\title{
Literatura
}

Mackie, J. (1977). Ethics. Inventing Right and Wrong. Penguin: London:.

Parfit, D. (2011). On What Matters. Oxford University Press: Oxford.

Shafer-Landau, R. (2003). Moral Realism. A Defence. Oxford University Press: Oxford. DOI: 10.1093/0199259755.001.0001

Stier, M. (2013). Normative preconditions for the assessment of mental disorder. Frontiers in Psychology 4(611). DOI: 10.3389/fpsyg.2013.00611

\begin{abstract}
In Marco Stier's article "Normative preconditions for the assessment of mental disorder," the concept of the normative occupies a central role (Stier, 2013). Stier states that mental disorders have an irreducible normative element built in, expressible through various "normative frames of reference" they are tied to. Following his two main theses, he thinks that these frameworks shape what counts as deviant as well as non-deviant behavior. He takes this as evidence that we have to specify mental disorders at the mental level, and thus will never be able to give a purely physical account of them. Unfortunately, he nowhere makes clear what he takes to be the content of the concept of the normative, although he gives some hints about his understanding at various passages. In what follows, I will explore three of his implicit suggestions on the essential linkages his concept of the normative bears to other concepts: the non-natural, the non-objective, and the relative. I shall argue that it is questionable that this understanding leads to the conclusion Stier aims at-that the specification of mental disorders cannot be succeed on the physical but only the mental level due to the impact of normative considerations in this enterprise.
\end{abstract}

Keywords: concept of mental disorder; non-natural; objectivity; relativity; normativity 